\title{
Srdeční frekvence a prognóza nemocných s chronickým srdečním selháním
}

\begin{abstract}
Na nedávném XIX. výročním sjezdu České kardiologické společnosti v Brně byly na satelitním sympoziu společnosti Servier komentovány závěry nových analýz studie SHIFT s ivabradinem. Její výsledky ukázaly, že nejen u anginy pectoris, ale i u chronického srdečního selhání je zpomaleni srdeční frekvence léčebným mechanismem, který velmi príznivě ovlivňuje prognózu nemocných.
\end{abstract}

Dnes už víme, že srdeční frekvence (SF) je ukazatelem kardiovaskulárního $(\mathrm{KV})$ rizika a je nám také známo, že čím jsou její klidové hodnoty vyšší, tím je toto riziko závažnější. „Studie SHIFT vycházela z předpokladu, že SF je rizikovým faktorem, a jejím cílem bylo zjistit, zda zpomalení SF pomocí ivabradinu zlepšuje prognózu nemocných s chronickým srdečním selháním (CHSS), "ř́íká na úvod její národní koordinátor, prof. MUDr. Jiří Vítovec, CSc., FESC, z I. interní kardio-angiologické kliniky LF MU a FN u svaté Anny v Brně. Studie SHIFT je dvojitě zaslepená studie, do které mohli být zařazeni pouze nemocní s CHSS se $\mathrm{SF} \geq 70$ tepů/min, zjištěnou při dvou na sobě nezávislých měřeních. Museli mít sinusový rytmus a dostávali $2 \times$ denně ivabradin $\mathrm{v}$ dávce $5 \mathrm{mg}$, která mohla být podle tolerance zvyšována až na $2 \times$ denně $7,5 \mathrm{mg}$. Po podávání ivabradinu byla podle očekávání zpomalena SF, došlo ale rovněž k významnému zjištění v oblasti primárního kombinovaného cíle studie, což byla redukce počtu úmrtí z KV prŕčin a počtu hospitalizací pro srdeční selhání.

\section{Studie SHIFT: Co zjistila nová analýza?}

Prof. Vítovec dále představuje výsledky nové analýzy studie SHIFT, kde bylo sledováno, zda je SF při vstupu do studie a při terapii ivabradinem určující pro výskyt sledovaných KV ukazatelů u pacientů se srdečním selháním a systolickou dysfunkcí. „Metodika této analýzy spočívala $v$ tom, že byl sledován vztah mezi SF a rizikem $K V$ prríhod $v$ placebové větvi. SF byla rozdělena na kvintily (od 70 tepů/min až po $\geq 87$ tepů/min) a hodnoty SF, kterých nemocní dosáhli 28. den terapie ivabradinem, byly vztaženy $k$ pozdějšímu výskytu KV př́hod. Vliv ivabradinu na výskyt těchto príhod byl upraven na známé prognostické a třídové faktory (např́klad věk, etiologie, hypertenze a diabetes mellitus) a byl přepočten podle stanovených kvintilù SF. V podstatě byly hodnoceny podobné parametry jako v hlavní studii, "vysvětluje prof. Vítovec.

Bylo zjištěno, že nemocní s CHSS, kteří měli vstupní srdeční frekvenci nejvyšší, byli nejčastěji hospitalizováni a nejčastěji také umírali. Pokud byly výsledky vztaženy na jednotlivé kvintily, v nejnižším kvintilu se vstupní srdeční frekvencí v intervalu 70-72 tepů/min bylo riziko rovno jedné, dále pak se stoupající hodnotou SF narůstal výskyt obou parametrů primárního kombinovaného cíle, tzn. jak rizika úmrtí z KV př́čin, tak hospitalizace pro zhoršené srdeční selhání. Zásadním zjištěním studie bylo, že SF dosažená léčbou ivabradinem je určující pro budoucí výskyt KV př́hod. Asi nepřekvapí, že 28. den měli pacienti v placebové větvi nejvyšší tepovou frekvenci a naopak - nemocní na ivabradinu se pohybovali v nejnižších sledovaných kvintilech. Ve vztahu k primárnímu kombinovanému cíli studie na tom byli nejlépe jedinci s dosaženou $\mathrm{SF}<60$ tepů/min. Pacienti, u kterých navzdory terapii SF poklesla nedostatečně, vykazovali rovněž vyšší výskyt hospitalizací a úmrtí (obrázek 1).

Co se týče vztahu mezi primární klidovou SF a výskytem kombinovaného ukazatele - čím vyšší byly její hodnoty, tím lepšího účinku dosahoval ivabradin při jejím snižování. Podobně pozitivní zde byly oba parametry primárního kombinovaného ukazatele studie. Prof. Vítovec v této souvislosti zmiňuje zajíma-

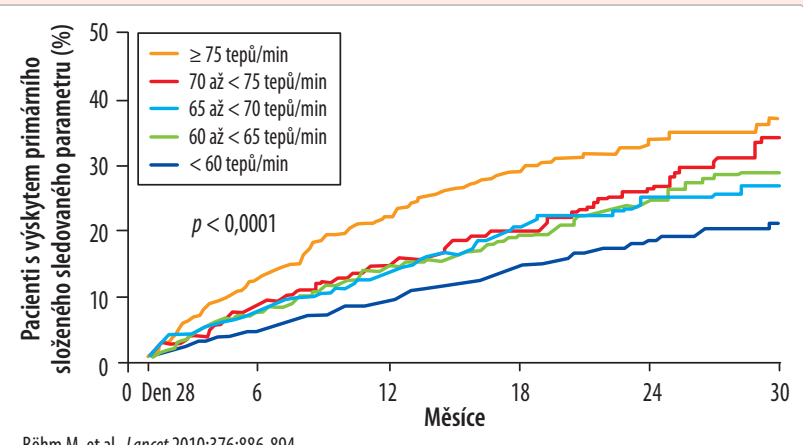

Böhm M. et al. Lancet 2010;376:886-894.

Obrázek 1 Absolutní SF dosažená při léčbě ivabradinem má přímý terapeutický význam pro snižení výskytu kardiovaskulárních příhod. Kaplanovy-Meierovy křivky kumulativního výskytu příhod zahrnutých do primárního složeného sledovaného ukazatele (tj. KV mortalita/hospitalizace pro srdeční selhání) ve skupině s ivabradinem podle kvintilů SF dosažené 28. den léčby ivabradinem. Pacienti, kteři dosáhli primárního kombinovaného ukazatele v prvních 28 dnech sledování, nebyli do analýzy zahrnuti.

vý článek v časopise American Journal of Cardiology z letošního března ke studii BEAUTIFUL. Zde byli sledováni nemocní se systolickou dysfunkcí ischemické etiologie. U podskupiny 840 pacientů bylo provedeno holterovské vyšetření. Kromě očekávaného snížení SF po podávání ivabradinu zde bylo prokázáno, že k tomuto poklesu došlo během celých 24 hodin a pokles byl udržován po celou dobu sledování. Míra snížení SF po ivabradinu byla závislá na výchozí hodnotě SF a byla menší v nočních hodinách oproti denním. Nebyl prokázán žádný nárůst výskytu závažné bradykardie, poruch vedení či rytmu, včetně výskytu síňové fibrilace oproti placebu (tabulka 1).

„Výsledky analýzy placebové větve studie SHIFT ukázaly, že u srdečního selhání se sinusovým rytmem a tepovou frekvencí $\geq 70$ tepů za minutu existuje prímý vztah mezi vstupní SF a zvyšujícím se $K V$ rizikem, přičemž toto riziko je výrazně sníženo ivabradinem. Účinek tohoto léčiva přitom závisí na počáteční hodnotě SF a na SF dosažené léčbou, " hodnotí prof. J. Vítovec a dodává, že zvýšená SF u srdečního selhání je rizikovým faktorem a měla by být parametrem, který je při léčbě nutno pečlivě sledovat a pokoušet se jej za každou cenu příznivě ovlivnit. Nižší vstupní SF a snížení srdeční frekvence po podávání ivabradinu je spojeno s lepší prognózou, přičemž tento benefit stoupá až $\mathrm{k}$ hodnotám 60 tepů/min, pokud nemocný tuto frekvenci toleruje.

\section{Marker i rizikový faktor}

Pokud v klinické praxi přemýšlíme o zahájení bradykardizující léčby, měli bychom si ujasnit, zda má ovlivnění SF pro další prognózu nemocných nějaký význam. Data z velkých klinických studií jednoznačně říkají, že SF je markerem i rizikovým faktorem. „Už výsledky studie BEAUTIFUL ukázaly, že se budoucnost 


\begin{tabular}{|c|c|c|c|c|c|c|c|}
\hline & \multicolumn{3}{|c|}{ Ivabradin ( $n=408)$} & \multicolumn{3}{|c|}{ Placebo $(n=399)$} & \multirow{2}{*}{$\begin{array}{l}\text { Význam- } \\
\text { nost } \\
\text { rozdílu }\end{array}$} \\
\hline & Výchozí & $\begin{array}{l}\text { Po jednom } \\
\text { měsíci }\end{array}$ & $\begin{array}{l}\text { Poslední měření } \\
\text { při léčb̌̌ }\end{array}$ & Výchozí & $\begin{array}{l}\text { Po jednom } \\
\text { měsíci }\end{array}$ & $\begin{array}{l}\text { Poslední měření } \\
\text { při léčbě }\end{array}$ & \\
\hline Fibrilace síní & $0(0 \%)$ & $3(0,8 \%)$ & $4(1 \%)$ & $2(0,5 \%)$ & $1(0,3 \%)$ & $5(1 \%)$ & NS \\
\hline Supraventrikulární tachykardie & $4(1 \%)$ & $4(1 \%)$ & $6(2 \%)$ & $1(0,3 \%)$ & $2(0,5 \%)$ & $5(1 \%)$ & NS \\
\hline Komorové tachykardie* & $96(24 \%)$ & $94(24 \%)$ & $98(26 \%)$ & $90(23 \%)$ & $100(26 \%)$ & $93(24 \%)$ & NS \\
\hline AV blokáda & $5(1 \%)$ & $6(2 \%)$ & $8(2 \%)$ & $7(2 \%)$ & $8(2 \%)$ & $7(2 \%)$ & NS \\
\hline Závažné bradykardie** & $0(0 \%)$ & $2(0,5 \%)$ & $1(0,3 \%)$ & $4(1 \%)$ & $5(1 \%)$ & $4(1 \%)$ & NS \\
\hline
\end{tabular}

Tabulka 1 Kardiální bezpečnost ivabradinu byla potvrzena 24hodinovým holterovským monitorováním EKG v podstudii BEAUTIFUL Holter na skupině 840 pacientů. Nebyl zaznamenán rozdíl v incidenci poruch rytmu a vedení mezi skupinou placeba a ivabradinu.

* Všechny nesetrvalé, trvající < $30 \mathrm{~s}$; ** SF < 30/min kdykoli během 24 hodin.

Tendera M, et al. Am J Cardiol 2011;107:805-811.

nemocných může lišit, a to v závislosti na tom, zda je jejich SF nižši či vyšši než arbitrárně stanovená hranice 70 tepů/min. A například $u$ nemocných po infarktu myokardu či s ischemickou chorobou srdeční (ICHS) můžeme podle hodnoty jejich tepové frekvence predpovědět pravděpodobnost, zda budou hospitalizováni či nikoli. Terapeutické snižování SF pozitivně ovlivňuje celou řadu dalších $K V$ morbidit. U pacientů s ICHS bylo toto príznivé působení prokázáno napríklad lepši tolerancí zátěže v ergometrických studiích, antianginózní efekt byl potvrzen ve studii BEAUTIFUL, kde došlo také např́klad k výraznému poklesu výskytu infarktu myokardu, a prognostický prínos u pacientůs CHSS byl prokázán ve studii SHIFT, " vypočítává MUDr. Jozef Jakabčin z Kardiologické kliniky Masarykovy nemocnice v Ústí nad Labem.

\section{Ivabradin $\vee$ klinické praxi}

MUDr. Jakabčin uvádí, že terapeutické snižování SF by mělo být prioritně nabízeno těm nemocným s ICHS či CHSS, kteří si stěžují na přetrvávající symptomy. Právě u nich totiž dochází $\mathrm{k}$ nejlepší odpovědi na léčbu a $\mathrm{k}$ nejvýraznějšímu ovlivnění prognózy - např́iklad u nemocných s limitující anginou pectoris a $\mathrm{SF} \geq 70$ tepů/min, kteří užívali ivabradin, došlo ve studii BEAUTIFUL ke $73 \%$ snížení výskytu infarktů myokardu. Ivabradin je také bezpečný lék. Bylo jednoznačně prokázáno, že v dávce $2 \times 5 \mathrm{mg}$ či $7,5 \mathrm{mg}$ /den je nemocnými dobře tolerován, a to i v kombinaci s beta-blokátory, zároveň zde nebyly prokázány žádné proarytmogenní účinky.

MUDr. Jakabčin dále představil několik zajímavých př́íladů z klinické praxe. „U pacientů s ICHS je dnes $v$ kardiologických ambulancích velmi často indikován beta-blokátor. Někdy ale bývaji problémem kontraindikace a nesnášenlivost těchto léčiv. Postupujeme skutečně správně, když takovým nemocným nenabízíme dalši farmakoterapii? Můžeme zvyšovat dávky beta-blokátorů?", ptá se a demonstruje př́pad 68letého muže se silně symptomatickou anginou pectoris, komplikovanou chronickou obstrukční plicní nemocí a dušností IV. stupně. Pacient měl dobrou systolickou funkci a sinusovou tachykardii (průměrně 100 tepů/min). Na koronarografii byly prokázány významné periferní stenózy $\mathrm{v}$ oblasti ramus posterolateralis dexter a ramus interventricularis posterior bez možnosti intervenční léčby. Pro opakovanou intoleranci beta-blokátorů při závažném plicním onemocnění byl aplikován ivabradin se zřejmým terapeutickým účinkem.

Druhý popisovaný pacient je ischemik, kterému byl před lety proveden $\mathrm{v}$ rámci revaskularizační terapie aorto-koronární bypass. Posléze začal docházet do kardiologické ambulance kvůli symptomatické angině pectoris, komplikované navíc ischemickou chorobou dolních končetin (klaudikace po 50 metrech chůze). „Nebylo žádným prekvapením, že zde byla zjištěna povšechná ateroskleróza v koronárním řečišti. Nemocnému byla doporučena konzervativní farmakoterapie a podobně jako v predešlém prípadě byl podán ivabradin, "uvádí MUDr. Jakabčin.

V oblasti léčby CHSS prezentuje MUDr. Jakabčin zkušenosti u několika pacientů s ischemickou i dilatační kardiomyopatií (NYHA II-III, s resynchronizační terapií, ejekční frakcí levé komory $<30 \%$ a srdeční frekvencí $\geq 70$ tepů/min), kterým byl na základě výsledků studie SHIFT podán ivabradin se snahou o maximální ovlivnění srdečního selhání, s cílem zlepšit prognózu a kvalitu života. Pacienti byli léčeni podle platných doporučení, užívali inhibitory ACE a beta-blokátory. „U všech sledovaných došlo $k$ poklesu SF a ke zlepšení symptomatologie onemocnění. Většina ivabradin dobře snášela. U nemocné s biventrikulární stimulací při kardio-resynchronizační léčbě a při zachovalém sinusovém rytmu, u níž SF dosahovala v prüměru 90 tepů/min, byl s výhodou doporučen ivabradin. Ten snízil průmèrnou i zátěžovou SF při zachování sinusového rytmu a při zvýšení variability SF. Pacientka popisovala, že se cití velmi dobře, zvýšila dokonce svou pohybovou aktivitu, kterou jsme zaznamenali objektivně akcelerometrem přistroje. Díky léčbě ivabradinem bylo dosaženo výhodné pomalejši tepové frekvence s kontraktilní rezervou, "vypočítává MUDr. Jakabčin.

\section{Beta-blokátory a ivabradin u srdečního selhání}

Bylo prokázáno, že zpomalení SF přináší nemocným s CHSS prospěch. Existuje metaanalýza řady klinických studií týkajících se srdečního selhání, která sledovala souvislosti mezi změnou SF navozenou prŕslušnou léčbou a změnou mortality. „Bylo zjištěno, že ve studiích, kde byla proporcionálně zpomalena SF uživáním beta-blokátorů, došlo ke snižení mortality. A naopak všechny studie, kde byla podána např́klad sympatomimetika, inhibitory fosfodiesterázy III či vasodilatancia a došlo zde ke zvýšení SF, byly předčasně ukončeny kvưli nárůstu mortality, "ř́ká prof. MUDr. Jaromír Hradec, CSc., FESC, z 3. interní kliniky 1. LF UK a VFN v Praze. O beta-blokátorech tedy víme, že zpomalují SF. Tím, že dojde k poklesu tepové frekvence, se u nemocných s CHSS snižuje i mortalita a výskyt velkých KV př́ihod, což bylo zjištěno např́íklad ve zmiňované studii BEAUTIFUL. U pacientů, kteří měli výchozí $S F \geq 70$ tepů/min, došlo po jejím zpomalení ivabradinem k významné redukci výskytu koronárních př́hod.

$\mathrm{V}$ současnosti máme tedy $\mathrm{k}$ dispozici dvě negativně chronotropní léčiva - ivabradin a skupinu beta-blokátorů. Zatímco ivabradin má pouze a výhradně bradykardizující účinek, beta-blokátory vykazují řadu dalších účinků, např́íklad snižují inotropii myokardu, zpomalují zde vedení elektrických vzruchů, mění elektrickou dráždivost a diastolické vlastnosti levé komory a př́znivě ovlivňují patologickou neurohumorální aktivaci. „Tyto dalši účinky mohou být prospěšné, může tomu být ale i naopak. Některé z nich mohou oslabovat klinický prospěch, vyplývající 
z negativně chronotropního účinku, “ ř́iká prof. Hradec. V experimentu bylo např́klad prokázáno, že beta-blokátory při zátěži snižují dilataci věnčitých tepen, neumožňují tedy v této situaci fyziologické zvýšení koronárního průtoku, zatímco ivabradin vasodilataci v koronárním řečišti v závislosti na zátěži zachovává. Experimentálně intravenózně podávaný ivabradin významně zpomaluje srdeční frekvenci, zároveň ale dochází ke zvyšování tepového objemu - se zpomalující se srdeční frekvencí tedy zůstává zachován srdeční výdej (obrázek 2). Ve stejném pokusu ivabradin nevedl $\mathrm{k}$ poklesu krevního tlaku, ani neovlivňoval systémovou vaskulární rezistenci.

Zpomalení SF má odlišné důsledky v závislosti na použité účinné látce. Naše současná doporučení využívají zkušeností získaných z klinických studií s beta-blokátory a neliší se od evropských ani amerických guidelines. „Říkají, že bychom se $u$ našich pacientů se selhávajícím srdcem měli pokusit dosáhnout cílových dávek beta-blokátorů, které byly vyzkoušeny v klinických studiích. Ani zdaleka se nám to však v klinické praxi nedaří, ve skutečnosti tyto dávky užívá pouze 23 \% nemocných, téměr̆ každý druhý pacient nedosáhne ani na poloviční dávku, i když víme, že zpomalení SF sniží mortalitu. Podle metaregresních analýz každé snižení SF o 12 tepů za minutu redukuje mortalitu o $24 \%$, "upozorňuje prof. Hradec. Jiná metaregresní analýza říká, že snížení mortality vůbec nesouvisí s dávkou beta-blokátorů, ale $s$ dosaženou tepovou frekvencí při léčbě - naprosto klíčová je tedy cílová SF (tabulka 2).

Ze studií SHIFT a BEAUTIFUL rovněž víme, že ivabradin lze bezpečně kombinovat $\mathrm{s}$ beta-blokátory. Nemocným, u kterých jsou beta-blokátory kontraindikovány nebo je netolerují, př́padně je kvůli limitujícím vedlejším účinkům (ve vyšších dávkách mohou způsobovat až síňo-komorové blokády, jejich dávka je rovněž limitována symptomatickou bradykardií a hypotenzí) musejí užívat v redukovaných dávkách, a nedosahují tak hodnot $\mathrm{SF}<70$ tepů/min (takových pacientů je podle Euro

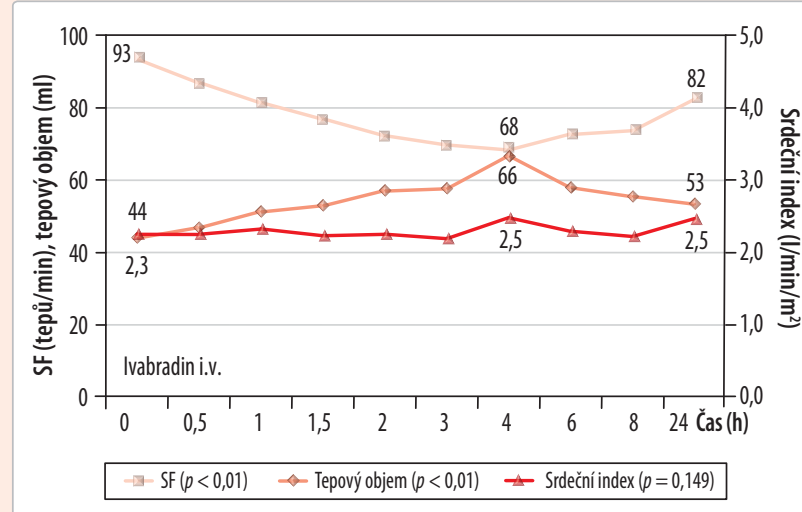

De Ferrari GM, et al. Eur J Heart Fail. 2008;10:550-555 SF - srdečni frekvence

Obrázek 2 Experimentálně intravenózně podávaný ivabradin významně redukoval srdeční frekvenci, zároveň ale došlo ke zvýšení tepového objemu.

Heart Survey $40 \%$ a ve studii SHIFT jich bylo $89 \%$ ), je možné $\mathrm{k}$ terapii přidat ivabradin, a dosáhnout tak optimální cílové SF. Ta by měla být u těchto nemocných 60 tepů/min. „Účinek ivabradinu na zpomalení tepové frekvence je aditivní a podle mého názoru leží budoucnost v kombinační terapii. Pacientům, kteři nemohou kvůli nežádoucím účinkưm dosáhnout na maximální dávky beta-blokátorů, a jejichž SF se nachází nad hranicí 70 tepů/min, můžeme přidáním ivabradinu ke stávající terapii významně zlepšit prognózu. Nezáleží zřejmě na tom, čím požadované hodnoty 60 tepư/min dosáhneme, zda beta-blokátory, ivabradinem či jejich kombinací. Dokonce se ukazuje, že kombinační terapie, především pro jedince, kteří nesnesou vyšši dávky beta-blokátorů, je velmi výhodná a dobře tolerovaná, “ uzavírá prof. Hradec.

\begin{tabular}{|c|c|c|c|c|}
\hline Potenciální modifikátory & Studie (n) & Pacienti (n) & Relativní rizika $(95 \% \mathrm{Cl})$ & $p$ \\
\hline Muži (\%) & 21 & 18773 & 0,93 (0,79-1,10) při 10\% zvýšení & 0,38 \\
\hline Průměrný věk & 21 & 18773 & $1,04(0,86-1,24)$ za deset let & 0,69 \\
\hline Srdeční selhání z ischemické př́íčiny (\%) & 21 & 18773 & 0,99 (0,86-1,14) při 20\% zvýšení & 0,88 \\
\hline Průměrná výchozí EF LK & 20 & 18392 & 1,04 (0,92-1,18) při 5\% zvýšení & 0,54 \\
\hline NYHA III-IV (\%) & 21 & 18773 & 1,00 (0,96-1,05) 10\% zvýšení & 0,84 \\
\hline Fibrilace síní (\%) & 8 & 8915 & 1,00 (0,91-1,09) při 5\% zvýšení & 0,95 \\
\hline Užívání digoxinu (\%) & 19 & 18336 & 1,01 (0,96-1,06) při 10\% zvýšení & 0,64 \\
\hline Vstupní SF & 19 & 17981 & $1,07(0,88-1,32)$ při $5 / \mathrm{min}$ & 0,47 \\
\hline Snížení SF & 17 & 17831 & $0,82(0,71-0,94)$ při $5 / \mathrm{min}$ & 0,006 \\
\hline Dávka beta-blokátorů & 17 & 17660 & 1,02 (0,93-1,10) při zvýšení & 0,69 \\
\hline Průměrný vstupní sTK & 17 & 17516 & $1,00(0,73-1,35)$ při $20 \mathrm{~mm} \mathrm{Hg}$ & 0,99 \\
\hline Průměrné snížení sTK & 10 & 5462 & $1,02(0,87-1,20)$ při $2 \mathrm{~mm} \mathrm{Hg}$ & 0,78 \\
\hline Léčiva & 21 & 18773 & - & - \\
\hline - carvedilol & - & - & Literární údaje & - \\
\hline - bisoprolol & - & - & $1,05(0,82-1,35)$ & 0,68 \\
\hline - metoprolol & - & - & $1,03(0,77-1,38)$ & 0,85 \\
\hline - atenolol & - & - & $0,89(0,29-2,76)$ & 0,83 \\
\hline - bucindolol & - & - & $1,36(1,09-1,69)$ & 0,009 \\
\hline - nebivolol & - & - & $1,30(0,99-1,71)$ & 0,056 \\
\hline
\end{tabular}

Tabulka 2 Metaregresní analýza 23 studií s beta-blokátory u srdečního selhání ( $n=19209$ pacientů). Analýza vztahu změny SF a rizika úmrtí ukázala, že vliv na mortalitu byl závislý na velikosti poklesu SF, nikoli na použité dávce beta-blokátoru. Souhrnný HR pro riziko úmrtí = 0,76 na každý pokles SF o 12 tepů/min.

McAlister et al. Ann Intern Med. 2009;150:784-794. EF LK - ejekční frakce levé komory 